Pomáhajúce profesie, roč. 3, č. 1, 2020, 5-19

\title{
THE RELATIONSHIP BETWEEN EARLY MALADAPTIVE SCHEMAS AND ATTACHMENT
}

\author{
Jaroslav Lukáč, Marta Popelková \\ Department of Psychological Sciences, Faculty of Social Sciences and Health Care, \\ Constantine the Philosopher University in Nitra \\ jaroslav.lukac@ukf.sk,mpopelkova@ukf.sk
}

\begin{abstract}
The conceptual model of schema therapy proposes that the unfulfilled need for secure attachments in childhood might lead to the development of Early Maladaptive Schemas. Yet to this day, there have been very few studies examining the relationships between Early Maladaprive Schemas, schema domains and different dimensions of attachment, as well as attachment styles. The objective of the present study was to review the findings from published studies regarding the relationship between Early Maladaptive Schemas and attachment. Thierteen studies met the inclusion criteria. The findings point to the significant role of the Abandonment schema and the Disconnection/rejection schema domain when it comes to attachment.
\end{abstract}

Keywords: early maladaptive schemas, attachment, attachment dimensions, schema domains, attachment styles

\section{INTRODUCTION}

The term attachment describes the bond between a child and the person that is caring for the child, be it a parent or some other caregiver. Bowlby (1982) defines attachment as a lasting emotional bond characterized by the child's need to seek and retain closeness to a specific person, especially when the child is in distress. This person fulfills multiple needs in relation to the child, acting as a secure base that enables the child to explore it's surroundings, as well as a safe haven where the child can receive comfort when distressed. Ainsworth classified the basic attachment types of children into three categories - secure, insecure-ambivalent and insecure-avoiding (Ainsworth et al., 1978). A fourth type was later identified by Main \& Solomon (1990) - the disorganized type. These classifications and the procedures created to discern them enabled researchers to capture the changes in attachment behaviors over different developmental stages. During the preschool years a child's attachment behavior changes significantly (Meins, Bureau, Fernyhough; 2018). The use of the caregiver as a secure base for exploration begins to take on a verbal form rather than an observable, proximity-seeking behavior form (Moss et al., 2005). Allen \& Tan (2016) note that adolescence brings further changes to the attachment behaviors due to the rapid development of competence during adolescence. The child can suppress the dependence on the caregiver and orient more towards peer relationships that can take the place of the previous attachment relationships. This process is aided by the development of internal working models (IWM). Bowlby (1982) describes working models as representations of the world and of the child in it, with the aid of which he perceives events, forecasts the future, and constructs his plans. In the working model of the world that anyone builds, a key feature is his notion of who his attachment figures are, where they may be found, and how they may be expected to respond. Marrone (1998) defines internal working models as cognitive maps, representations, schemas, or scripts that an individual has about themselves and the environment.

Early maladaptive schemas (EMS) are also a type of cognitive representations. EMS represent a broad, pervasive theme or pattern regarding oneself and one's relationships with others, 
comprised of memories, emotions, cognitions, and bodily sensations that developed during childhood or adolescence and are dysfunctional to a significant degree (Young, Klosko, Weishar; 2003). Young (1999) suggests that EMS are the result of dysfunctional interactions with parents, siblings and peers during the first years of life. Schemas result from unmet core emotional needs in childhood, namely a need for secure attachments to others, a need for autonomy, a need for freedom to express needs and emotions, a need for spontaneity and a need for realistic limits and self-control (Young, Klosko, Weishar; 2003). Young (1999) identified four types of life experiences that result in the creation of EMS - toxic frustration of needs, traumatization or victimization, absence of autonomy or realistic limits and selective internalization or identification with significant others. Young, Klosko and Weishar (2003) described 18 individual EMS, which they grouped into five distinct schema domains. A review of the original model found that dividing the 18 EMS into four domains is more accurate (Bach, Lockwood, Young; 2017). The new model consists of the domains of "Disconnection \& Rejection", "Impaired Autonomy\& Performance", "Excessive Responsibility \& Standards", and "Impaired Limits". Young himself describes Early Maladaptive Schemas as dysfunctional internal working models, and sees children's characteristic responses to attachment figures as their coping styles (Young, Klosko, Weishar; 2003). Collins and Read (1994) suggested that working models contain four interrelated components; (a) autobiographical memories, (b) beliefs and attitudes, (c) goals and motives, and (d) behavioral strategies. Beliefs and attitudes seem to comprise the conscious elements to which the broader conception of schemas might appeal. According to Platts, Tyson and Mason (2002) it is possible that individual differences in attachment can be conceptualized as being due to differences in the beliefs people hold about themselves and others.

Research on the asssociation between attachment styles and Early Maladaptive Schemas has been sparse. We would therefore like to present a review of previous research findings regarding the relationship between EMS and attachment.

\section{PRESENT STUDY}

The aim of the present study is to provide an overview of the current research examining the relationship between EMS and attachment styles. We aim to identify relations between individual schemas pertaining to different attachment classifications. We also aim to review the subject of attachment classifications in relation to schema domains. Furthermore, we investigate whether attachment to parents, attachment to peers and attachment to romantic partners influence the presentation or presence of EMS and schema domains.

\section{METHODS}

A literature search was conducted using the keywords „attachment quality and early maladaptive schemas" and "attachment and early maladaptive schemas", focusing on studies published between the years 2000 and 2020. At this point, we identified 31 studies that were relevant to our search. We set our criteria for including studies as follows - the studies had to be published in English, Slovak or Czech; they had to report primary research; they had to be published in an international research database and they had to use quantitative methods for collecting their data. After excluding studies that did not examine direct relations between attachment and EMS we ended up with 13 studies that met all our inclusion criteria and thus were relevant to this review.

\section{RESULTS}

We identified 13 studies that were relevant to the goals of our review. We present basic information about the studies in the following table and we will sumarize and discuss the findings in the next section. 
Table 1 - Information about the reviewed studies

\begin{tabular}{|c|c|c|c|}
\hline $\begin{array}{l}\text { Authors \& } \\
\text { Country }\end{array}$ & Participants & Instruments & Key findings \\
\hline $\begin{array}{l}\text { Cecero, Nelson, } \\
\text { Gilllie; } 2004 \\
\text { USA }\end{array}$ & $\begin{array}{l}292 \text { university } \\
\text { students }(220 \\
\text { female, } 72 \text { male, } \\
\text { aged } 17-21 \text { years, } \\
\text { mean age }=20 \text { ) / } \\
\text { non-clinical } \\
\text { population }\end{array}$ & $\begin{array}{l}\text { EMSQ-R; RQ; } \\
\text { CTQ }\end{array}$ & $\begin{array}{l}\text { The 15-schema model was found to } \\
\text { significantly predict all four } \\
\text { attachment styles } \\
\text { No EMS positively predicted secure } \\
\text { adult attachment } \\
\text { Emotional deprivation and } \\
\text { Emotional inhibition were } \\
\text { significant negative predictors } \\
\text { Abandonment/Instability was } \\
\text { a significant positive predictor of } \\
\text { preoccupied attachment } \\
\text { Social isolation / Alienation and } \\
\text { Emotional deprivation were } \\
\text { significant predictors of dismissing } \\
\text { attachment } \\
\text { Mistrust/Abuse and Emotional } \\
\text { inhibition were significant positive } \\
\text { predictors of fearful attachment }\end{array}$ \\
\hline $\begin{array}{l}\text { Mason, Platts, } \\
\text { Tyson; 2005 } \\
\text { UK }\end{array}$ & $\begin{array}{l}72 \text { clients of out- } \\
\text { patient mental } \\
\text { health services } \\
\text { ( } 32 \text { male, } 40 \\
\text { female, aged 18- } \\
62 \text { years, mean } \\
\text { age=39) / clinical } \\
\text { population }\end{array}$ & $\begin{array}{l}\text { YSQ-SF; ECL; } \\
\text { CORE }\end{array}$ & $\begin{array}{l}\text { Schemas differed significantly } \\
\text { according to attachment style } \\
\text { grouping, with the fearful group } \\
\text { possessing the greatest degree of } \\
\text { maladaptive schemas, followed by } \\
\text { the preoccupied group } \\
\text { The secure group were } \\
\text { characterized by lower scores for } \\
\text { emotional deprivation, } \\
\text { abandonment,enmeshment,mistrust } \\
\text { /abuse, subjugation, social isolation, } \\
\text { defectiveness/shame, emotional } \\
\text { inhibition, and } \\
\text { dependence/incompetence } \\
\text { The fearful group was characterized } \\
\text { by greater social isolation, } \\
\text { defectiveness/shame, and } \\
\text { emotional inhibition } \\
\text { The preoccupied group was difficult } \\
\text { to distinguish as it largely fell } \\
\text { between the other two, however, } \\
\text { abandonment, subjugation, and } \\
\text { emotional deprivation scores were }\end{array}$ \\
\hline
\end{tabular}




\begin{tabular}{|c|c|c|c|}
\hline & & & $\begin{array}{l}\text { identified as characteristic for this } \\
\text { group. }\end{array}$ \\
\hline $\begin{array}{l}\text { Blisett et al., } \\
2006 \\
\text { UK }\end{array}$ & $\begin{array}{l}206 \text { female } \\
\text { sudents (aged 18- } \\
33 \text { years, mean } \\
\text { age }=19,8 \text { ) / non- } \\
\text { clinical } \\
\text { population }\end{array}$ & YSQ-SF; PAQ & $\begin{array}{l}\text { Mistrust/abuse, insufficient self- } \\
\text { control and emotional deprivation } \\
\text { significantly predicted participants' } \\
\text { perceptions of the affective quality } \\
\text { of their relationship with their } \\
\text { mother } \\
\text { Social isolation, enmeshment and } \\
\text { insufficient self-control significantly } \\
\text { predicted participants' perceptions } \\
\text { of their mother as a facilitator of } \\
\text { their independence } \\
\text { Emotional deprivation, } \\
\text { abandonment and social isolation } \\
\text { significantly predicted participants' } \\
\text { perceptions of their mothers as a } \\
\text { source of support } \\
\text { Mistrust/abuse, emotional } \\
\text { deprivation and abandonment } \\
\text { significantly predicted participants' } \\
\text { perceptions of the affective quality } \\
\text { of their relationships with their } \\
\text { fathers } \\
\text { Mistrust/abuse and emotional } \\
\text { deprivation significantly predicted } \\
\text { participants' perceptions of their } \\
\text { fathers as a facilitator of their } \\
\text { independence } \\
\text { Emotional deprivation and } \\
\text { mistrust/abuse significantly } \\
\text { predicted participants' perceptions } \\
\text { of their fathers as a source of } \\
\text { support }\end{array}$ \\
\hline $\begin{array}{l}\text { Bosmans, } \\
\text { Braet, } \\
\text { Vlierberghe; } \\
2010 \\
\text { Belgium }\end{array}$ & $\begin{array}{l}289 \text { students ( } 26 \\
\text { men, } 241 \text { women, } \\
22 \text { missing) with } \\
\text { a mean age of } 21 \\
\text { years / non- } \\
\text { clinical } \\
\text { population }\end{array}$ & $\begin{array}{l}\text { YSQ-SF; ECR-r; } \\
\text { SCL-90 }\end{array}$ & $\begin{array}{l}\text { Both attachment dimensions were } \\
\text { signifi cantly linked with all schema- } \\
\text { domains } \\
\text { Disconnection/Rejection and Other- } \\
\text { Directedness were linked to } \\
\text { attachment anxiety } \\
\text { Disconnection/Rejection and } \\
\text { Impaired Autonomy were linked to } \\
\text { attachment avoidance }\end{array}$ \\
\hline
\end{tabular}




\begin{tabular}{|c|c|c|c|}
\hline & & & $\begin{array}{l}\text { The effect of attachment anxiety on } \\
\text { symptoms of psychopathology was } \\
\text { completely mediated by the effect of } \\
\text { Disconnection/Rejection and Other- } \\
\text { Directedness } \\
\text { The effect of attachment avoidance } \\
\text { on symptoms of psychopathology } \\
\text { was partly mediated by } \\
\text { Disconnection/Rejection }\end{array}$ \\
\hline $\begin{array}{l}\text { Roelofs et al. } \\
2011 \\
\text { Netherlands }\end{array}$ & $\begin{array}{l}222 \text { adolescents } \\
\text { ( } 84 \text { boys, } 138 \\
\text { girls) aged } 12 \text { to } \\
18 \text { years (mean } \\
\text { age }=14.7 \text { year) / } \\
\text { non-clinical } \\
\text { population }\end{array}$ & $\begin{array}{l}\text { YSQ-A; IPPA; } \\
\text { BDI-II }\end{array}$ & $\begin{array}{l}\text { Trust in parents and peers were } \\
\text { significantly related to most } \\
\text { schemas, with correlations for } \\
\text { parents being somewhat higher } \\
\text { than for peers } \\
\text { Communication with parents, but to } \\
\text { a lesser extent with peers, was also } \\
\text { related to schemas } \\
\text { Alienation from parents and peers } \\
\text { was related to schemas, with } \\
\text { correlations for peers being } \\
\text { somewhat stronger than for parents } \\
\text { A significant, moderately strong } \\
\text { negative correlation was observed } \\
\text { between trust in parents and the } \\
\text { schemas of Mistrust/abuse and } \\
\text { Subjugation } \\
\text { A significant, moderately strong } \\
\text { positive correlation was observed } \\
\text { between alienation from peers and } \\
\text { the schema of Social } \\
\text { isolation/alienation } \\
\text { The disconnection and rejection } \\
\text { domain was a significant mediator } \\
\text { in the relation between trust in } \\
\text { parents and depressive symptoms as } \\
\text { well as between alienation from } \\
\text { peers and symptoms of depression }\end{array}$ \\
\hline $\begin{array}{l}\text { Simard, Moss, } \\
\text { Pascuzzo; } \\
2011 \\
\text { Canada }\end{array}$ & $\begin{array}{l}60 \text { participants } \\
(39 \text { females, } 21 \\
\text { males) aged } \\
\text { between } 5 \text { and } 7 \\
\text { years }(M=6 \\
\text { years) at Time I, } \\
19 \text { years, } 8 \\
\text { months to } 22\end{array}$ & $\begin{array}{l}\text { Separation- } \\
\text { reunion task } \\
\text { (Time I); ECR } \\
\text { (Time II), YSQ- } \\
\text { L3 (Time II) }\end{array}$ & $\begin{array}{l}\text { More signs of EMS among young } \\
\text { adults with either an insecure } \\
\text { ambivalent child attachment, or an } \\
\text { insecure preoccupied adult } \\
\text { attachment style, compared to their } \\
\text { secure peers }\end{array}$ \\
\hline
\end{tabular}




\begin{tabular}{|c|c|c|c|}
\hline & $\begin{array}{l}\text { years, } 8 \text { months } \\
(M=21 \text { years, } \\
2 \text { months) at } \\
\text { Time II / non- } \\
\text { clinical } \\
\text { population }\end{array}$ & & $\begin{array}{l}\text { Unmet childhood needs for secure } \\
\text { attachment may lead to a large } \\
\text { variety of EMS } \\
\text { Young adults classsified as insecure } \\
\text { ambivalent in childhood scored } \\
\text { higher than their securely attached } \\
\text { peers on } 11 \text { out of } 18 \text { EMS, with } \\
\text { emotional inhibition, } \\
\text { mistrust/abuse, subjugation, } \\
\text { approval-seeking and failure } \\
\text { highlihting the differences between } \\
\text { these groups } \\
\text { Preoccupied adults scored higher } \\
\text { than secure adults on } 10 \text { of } 18 \text { EMS } \\
\text { (abandonment/instability, } \\
\text { defectiveness/shame, failure, and } \\
\text { dependence/incompetence, } \\
\text { mistrust/abuse, social } \\
\text { isolation/alienation, vulnerability to } \\
\text { harm and illness, subjugation, } \\
\text { insufficient self-control/self- } \\
\text { discipline, and } \\
\text { negativity/pessimism) }\end{array}$ \\
\hline $\begin{array}{l}\text { Stanojevič, } \\
\text { Nedeljkovič; } \\
2012 \\
\text { Serbia }\end{array}$ & $\begin{array}{l}290 \\
\text { students of } \\
\text { psychology } \\
(253 \text { female and } \\
36 \text { male), aged } \\
19-36 \text { (mean age= } \\
20.26 \text { ) / non- } \\
\text { clinical } \\
\text { population }\end{array}$ & YSQ-SF; RQ & $\begin{array}{l}\text { Early maladaptive schemas are } \\
\text { significantly more present in groups } \\
\text { of insecurely attached respondents } \\
\text { The highest total score on the Young } \\
\text { Schema Questionnaire is achieved } \\
\text { by respondents with disorganized } \\
\text { attachment } \\
\text { Six maladaptive schemas are } \\
\text { characteristic for respondents with } \\
\text { the disorganized attachment pattern } \\
\text { when compared to the rest of the } \\
\text { attachment patterns (mistrust, } \\
\text { social isolation, emotional } \\
\text { inhibition, defectiveness, } \\
\text { vulnerability to harm and } \\
\text { unrelenting standards) } \\
\text { Failure, subjugation, abandonment, } \\
\text { dependence/incompetence, } \\
\text { enmeshment/symbiosis, and self- } \\
\text { sacrifice schemas are characteristic } \\
\text { for the preoccupied attachment } \\
\text { pattern }\end{array}$ \\
\hline
\end{tabular}




\begin{tabular}{|c|c|c|c|}
\hline & & & $\begin{array}{l}\text { Insufficient self-control, emotional } \\
\text { deprivation, and entitlement can be } \\
\text { used to partly distinguish } \\
\text { respondents with dismissing } \\
\text { attachment from the groups with } \\
\text { disorganized and secure attachment }\end{array}$ \\
\hline $\begin{array}{l}\text { Roelofs, } \\
\text { Onckels, Muris; } \\
2013 \\
\text { Netherlands }\end{array}$ & $\begin{array}{l}82 \text { adolescent } \\
\text { patients ( } 46 \text { boys } \\
\text { and } 36 \text { girls) aged } \\
12-18 \text { years; } \\
\text { clinical } \\
\text { population }\end{array}$ & $\begin{array}{l}\text { YSQ-A; } \\
\text { IPPA;SDQ }\end{array}$ & $\begin{array}{l}\text { IPPA peer subscales were more } \\
\text { convincingly connected to YSQ-A } \\
\text { schema domains than IPPA parent } \\
\text { subscales } \\
\text { Trust and communication were } \\
\text { negatively related to schema } \\
\text { domain scores } \\
\text { Positive correlations were observed } \\
\text { between alienation and schema } \\
\text { domain scores } \\
\text { Peer trust showed a significant and } \\
\text { strong negative correlation with the } \\
\text { Disconnection/rejection schema } \\
\text { domain, while the negative } \\
\text { correlation with parent trust was } \\
\text { relatively weak but significant } \\
\text { Peer trust showed a significant and } \\
\text { moderately strong negative } \\
\text { correlation with the Impaired } \\
\text { autonomy schema domain, while } \\
\text { the negative correlation with parent } \\
\text { trust was insignificant }\end{array}$ \\
\hline $\begin{array}{l}\text { McLean, } \\
\text { Bailey, Lumley; } \\
2014 \\
\text { Canada }\end{array}$ & $\begin{array}{l}146 \text { (95 female, } \\
51 \text { male) } \\
\text { undergraduate } \\
\text { students enrolled } \\
\text { in a first year } \\
\text { Psychology } \\
\text { course }- \text { mean } \\
\text { age = } 18.45, \text { SD = } \\
1.03 / \text { non-clinical } \\
\text { population }\end{array}$ & $\begin{array}{l}\text { SBS-RN; YSQ- } \\
\text { S2; ECR }\end{array}$ & $\begin{array}{l}\text { Attachment avoidance was most } \\
\text { strongly associated with the } \\
\text { Emotional Inhibition schema } \\
\text { Attachment anxiety was most } \\
\text { strongly correlated with the } \\
\text { Abandonment schema } \\
\text { A significant moderately strong } \\
\text { positive correlation was observed } \\
\text { between attachment anxiety and the } \\
\text { Subjugation schema } \\
\text { Attachment anxiety showed } \\
\text { significant correlations with every } \\
\text { individual schema except for } \\
\text { Entitlement, Self-sacrifice and } \\
\text { Unrelenting standards }\end{array}$ \\
\hline
\end{tabular}




\begin{tabular}{|c|c|c|c|}
\hline $\begin{array}{l}\text { Medalova, } \\
\text { Prochazka; } \\
2014 \\
\text { Czech Republic }\end{array}$ & $\begin{array}{l}48 \text { patients ( } 37 \\
\text { male, } 11 \text { female) } \\
\text { from an addiction } \\
\text { treatment clinic } \\
\text { (mean age } 40,1 \\
\text { for males and } \\
42,9 \text { for females) } \\
+ \text { a comparison } \\
\text { non-clinical group } \\
\text { of } 39 \text { adults ( } 8 \\
\text { male, } 31 \text { female) } \\
\text { with a mean age } \\
\text { of } 38,7 \text { years for } \\
\text { males and } 27,1 \\
\text { for females }\end{array}$ & $\begin{array}{l}\text { YSQ - } \\
\text { shortened; ECR; } \\
\text { SVF-78 }\end{array}$ & $\begin{array}{l}\text { Attachment anxiety was most } \\
\text { strongly correlated with the } \\
\text { Abandonment schema (in the whole } \\
\text { sample) } \\
\text { Attachment anxiety was also } \\
\text { moderately correlated with the } \\
\text { Insufficient self-control schema and } \\
\text { the Emotional inhibition schema (in } \\
\text { the whole sample) } \\
\text { Attachment avoidance was only } \\
\text { moderately correlated to the } \\
\text { Abandonment schema, the Social } \\
\text { isolation schema and the Emotional } \\
\text { inhibition schema (whole sample) } \\
\text { The greatest differences between } \\
\text { the clinical and non-clinical groups } \\
\text { were observed in relation to the } \\
\text { Abandonment schema, which } \\
\text { reached significantly higher values } \\
\text { among the clinical population } \\
\text { The Mistrust/abuse, Emotional } \\
\text { inhibition, Emotional deprivation, } \\
\text { Defectiveness/shame, Self-sacrifice, } \\
\text { Insufficient self-control, } \\
\text { Vulnerability and Subjugation } \\
\text { schemas also scored significantly } \\
\text { higher among the clinical } \\
\text { population }\end{array}$ \\
\hline $\begin{array}{l}\text { MacDonald et } \\
\text { al., } 2015 \\
\text { USA }\end{array}$ & $\begin{array}{l}100 \text { adult health- } \\
\text { care providers } \\
(93 \text { male, } 7 \\
\text { female, mean age } \\
=53 \text { ) / non- } \\
\text { clinical } \\
\text { population }\end{array}$ & $\begin{array}{l}\text { Structured } \\
\text { autobiography; } \\
\text { ECR-r; YSQ-S1; } \\
\text { CTQ }\end{array}$ & $\begin{array}{l}\text { Attachment anxiety was most } \\
\text { strongly correlated with the } \\
\text { Abandonment schema } \\
\text { Attachment anxiety was also } \\
\text { moderately correlated with the } \\
\text { Subjugation, Emotional deprivation, } \\
\text { Dependence, Vulnerability, } \\
\text { Defectiveness/shame and } \\
\text { Insufficient self-control schemas } \\
\text { Attachment avoidance was most } \\
\text { stongly related to the Subjugation } \\
\text { schema } \\
\text { Attachment avoidance was also } \\
\text { moderately correlated with the } \\
\text { Mistrust/abuse and Emotional } \\
\text { deprivation schemas } \\
\text { Attachment avoidance was } \\
\text { significantly correlated to only } 7\end{array}$ \\
\hline
\end{tabular}




\begin{tabular}{|c|c|c|c|}
\hline & & & $\begin{array}{l}\text { schemas (mentioned above }+ \\
\text { Emotional inhibition, Vulnerability, } \\
\text { Dependence and Isufficient self- } \\
\text { control) } \\
\text { The correlations between the } \\
\text { Enmeshment, Self-scrifice and } \\
\text { Unrelenting standards schemas and } \\
\text { attachment anxiety were not } \\
\text { significant }\end{array}$ \\
\hline $\begin{array}{l}\text { Langhinrichse } \\
\text { n-Rohling et al. } \\
2017 \\
\text { USA }\end{array}$ & $\begin{array}{l}766 \text { students } \\
\text { from a university } \\
\text { in the } \\
\text { southeastern } \\
\text { United States. The } \\
\text { sample: } 535 \\
\text { women }(70 \%) \text {, } \\
231 \text { men, mean } \\
\text { age of } 19.9 \text { years } \\
\text { (SD = } 3.7 \text { years). / } \\
\text { non-clinical } \\
\text { population }\end{array}$ & $\begin{array}{l}\text { YSQ-3SF; IPPA; } \\
\text { SIQ; LAS-SF }\end{array}$ & $\begin{array}{l}\text { Parental attachment was negatively } \\
\text { related to maladaptive schemas of } \\
\text { Abandonment, Defectiveness, and } \\
\text { Emotional deprivation } \\
\text { Poor parental attachment was } \\
\text { strongly associated with } \\
\text { defectiveness and emotional } \\
\text { deprivation } \\
\text { Maladaptive schemas mediated the } \\
\text { relation between parental } \\
\text { attachment and suicide proneness } \\
\text { and ideation }\end{array}$ \\
\hline $\begin{array}{l}\text { Kaya, Aydin, } \\
2020 \\
\text { Turkey }\end{array}$ & $\begin{array}{l}413 \text { university } \\
\text { students }(62.5 \% \\
\text { female, } 37,5 \% \\
\text { male) aged } \\
\text { between } 18 \text { and } \\
34 \text { years } \\
\text { (mean age=20.77) }\end{array}$ & YSQ-SF3; IPPA & $\begin{array}{l}\text { Attachment was observed to exert a } \\
\text { significant effect on the early } \\
\text { maladaptive schemas } \\
\text { Insecure attachment to the parents } \\
\text { activated the schema domains of } \\
\text { disconnection/rejection and } \\
\text { impaired autonomy } \\
\text { Insecure attachment to the mother } \\
\text { exerted a direct significant positive } \\
\text { effect on impaired autonomy and } \\
\text { disconnection/rejection schema } \\
\text { areas } \\
\text { Insecure attachment to fathers } \\
\text { exerted a direct significant positive } \\
\text { effect on disconnection/rejection } \\
\text { and impaired autonomy schema } \\
\text { areas } \\
\text { The disconnection/rejection } \\
\text { schema was observed to } \\
\text { significantly and positively mediate } \\
\text { insecure attachment in explaining } \\
\text { depression and anxiety symptoms }\end{array}$ \\
\hline
\end{tabular}


Pomáhajúce profesie, roč. 3, č. 1, 2020, 5-19

\section{DISCUSSION \\ Instruments used to measure attachment}

Before discussing the relevant findings from the reviewed studies, we would like to introduce the different instruments used for measuring attachment and attachment related constructs used in the reviewed studies. 6 out of the 13 studies that we reviewed used the ECR or it's revised form, the ECR-r. The ECR (Brennan, Clark, Shaver; 1998) evaluates adult romantic attachment along two dimensions: avoidance of intimacy and anxiety over abandonment as manifested in the specific context of romantic relationships (Simard, Moss, Pascuzzo; 2011). The measure consists of two 18item scales measuring anxiety and avoidance (or model of the self and other) where each item is scored on 7-point Likert scale. A high score on the anxiety scale identifies Bartholomew's preoccupied category, high scores on the avoidance scale identifies the dismissing category, and high scores on both scales identify the fearful category. The ECR-r (Fraley, Waller, Brennan; 2000) consists of 36 items that have to be rated with regard to the 'important other' (measuring the general internal working model) on a 7-point Likert scale (Bosmans, Braet, Vlierberghe; 2010). The items are designed to assess two dimensions of attachment: attachment anxiety (18 items about fear of abandonment and need for contact) and attachment avoidance (18 items about discomfort with closeness). 4 out of the 13 studies that we reviewed used the Inventory of Parent and Peer Attachment (IPPA; Armsden and Greenberg, 1987) to measure attachment. The IPPA is a 53-item self-report instrument that assesses positive and negative affective and cognitive dimensions of adolescents' relationships with their parents (28 items) and close friends (25 items). The IPPA consists of three scales: trust (e.g. degree of mutual understanding and respect in the attachment relationship), communication (e.g. extent and quality of spoken communication), and alienation (e.g. feelings of anger and interpersonal alientation). The Relationship Questionnaire (RQ; Bartholomew \& Horowitz, 1991) was used in two of the reviewed studies. The RQ is based on a four-style, two-dimensional model of individual differences in adult attachment (Platts, Tyson, Mason; 2002). The two dimensions underlying the four styles are the positivity of the person's self image (model of self) and the positivity of the person's image of others (model of other). The models of 'self' and 'other' are also referred to as dimensions of anxiety (about abandonment) and avoidance (of intimacy and emotional expression). This conceptualization provides four attachment styles (secure, fearful, preoccupied and dismissing), similar to the ECR and ECR-r. The questionnaire was originally designed to measure general adult attachment orientations toward "others." However, Bartholomew recommends rewording the RQ to adapt it to the individual relationship-specific orientations being studied (Donbaek, Elklit; 2014). The Parental Attachment Questionnaire (PAQ; Kenny, 1987) was used in one of the reviewed studies. The PAQ is a 55-item, five-point Likert scale used to investigate the views of young adults about their attachment relationships with their parents. There are three subscales (affective quality of relationships, parents as facilitators of independence, parental source of support).

\section{Early Maladaptive Schemas and attachment to parents}

Five of the reviewed studies investigated the specific relationship between EMS and attachment to parents. The instruments used in these studies were the IPPA and the PAQ. The findings seem to suggest that the attachment relationship to the father is strongly influenced by the EMS of Mistrust/abuse, Emotional deprivation, although this may be true only for women, as the study that reported these findings used only female participants (Blisett et al. 2006). In addition, the EMS of Abandonment seems to contribute in a significant way to the affective quality of the relationship with fathers, acting in conjunction with the EMS of Mistrust/abuse and Emotional deprivation. The relationship between young women and their mothers seems to be also influenced by a limited number of EMS. The EMS of Emotional deprivation, Social isolation and Insufficient self-control, combined with other schemas, influences various aspects of the relationships between mothers and daughters. These findings seem to be partially supported by the findings from Langhinrichsen- 
Roling et al. (2017), who reported that poor parental attachment was strongly associated with Emotional deprivation, but also with the schema of Defectiveness. The parental attachment quality also showed a negative relation to the schema of Abandonment. Kaya \& Aidin (2020) report that insecure attachment to the parents activated the schema domains of Disconnection/rejection and Impaired autonomy schema domains, which include all of the aforementioned schemas, except for the Insufficient-self control schema. Therefore, it seems that the schema domains of Disconnection/rejection and Impaired autonomy are the most relevant when it comes to examining relationships between attachment to parents and EMS.

\section{Early Maladaptive Schemas and attachment to peers}

Only two of the reviewed studies reported on the relationships between EMS and attachment to peers specifically. Roelofs, Onckels and Muris (2013) noted that Peer trust showed a significant and strong negative correlation with the Disconnection/rejection schema domain and a moderately strong negative correlation with the Impaired autonomy schema domain. Roelofs et al. (2011) repported a significant, moderately strong positive correlation between alienation from peers and the schema of Social isolation/alienation, which is supported by the moderate correlation between alienation from peers and the Disconnection/rejection schema domain that was observed by Roelofs, Onckels, Muris (2013). Although one might expect that for adolescents and young adults, attachment to peers would be more suitable to predict EMS, since adolescents tend to orient more towards peer relationships than parental relationships (Allen \& Tan, 2016), the findings reported in our review were inconclusive on this matter. One explanation might be that since EMS tend to develop earlier, when the child is still primarily attached to its parents, and since EMS are partially resistant to change, then peer attachment relationships are not able to override these earlier experiences and the cognitions that stem from them.

\section{Early Maladaptive Schemas and attachment dimensions}

Bosmans, Braet \& Vlierberghe (2010) reported that both of the attachment dimensions of anxiety and avoidance were significantly linked with all schema domains. Disconnection/Rejection and Other-Directedness schema domains were linked to attachment anxiety, while Disconnection/Rejection and Impaired Autonomy schema domains were linked to attachment avoidance. When it comes to individual EMS, McLean, Bailey and Lumley (2014) repoted that attachment anxiety was most strongly correlated with the Abandonment schema. Medalova and Prochazka (2014), as well as MacDonald et al. (2015) also noted that the relationship between attachment anxiety and the Abandonment schema showed the highest correlation. According to McLean, Bailey and Lumley (2014) the attachment avoidance dimension was most strongly associated with the Emotional Inhibition schema, but the study conducted by MacDonald et al. (2015) found the strongest correlations with the Subjugation schema.

\section{Early Maladaptive Schemas and attachment styles}

In all of the reviewed studies focusing on the relationship between EMS and attachment styles, the securely attached respondents showed the lowest scores in EMS, compared to insecurely attached respondents. Cecero, Nelson and Gillie (2004) reported that no individual EMS positively predicted secure adult attachment, while Mason, Platts and Tyson (2005) noted that securely attached respondents were characterized by lower scores for Emotional deprivation, Abandonment, Enmeshment, Mistrust/abuse, Subjugation, Social isolation, Defectiveness/shame, Emotional inhibition and Dependence/incompetence. Simard, Moss and Pascuzzo (2011) observed that EMS of Emotional inhibition, Mistrust/abuse, Subjugation, Approval-seeking and Failure show the most differences when comparing young adults who were securely or insecurely attached as children.

When examining the relationship between preocuppied attachment and EMS, Cecero, Nelson and Gillie (2004) found that the schema of Abandonment/Instability was a significant positive predictor of preoccupied attachment. Mason, Platt and Tyson (2005) described Abandonment, Subjugation and Emotional deprivation as characteristic for preoccupied attachment groups, when 
trying to discern them from other types of attachment. Stanojevic and Nedeljkovic (2012) identified Failure, Subjugation, Abandonment, Dependence/incompetence, Enmeshment/symbiosis, and Self-sacrifice schemas as characteristic for the preoccupied attachment pattern. Simard, Moss and Pascuzzo (2011) reported that preoccupied adults scored higher than secure adults on 10 of 18 EMS, with Abandonment scores showing the most difference between both groups.

Fearful attachment was positively predicted by EMS of Mistrust/abuse and Emotional inhibition (Cecero, Nelson, Gillie; 2004). The fearful group possesses the greatest degree of maladaptive schemas and is characterized by greater Social isolation, Defectiveness/shame, and Emotional inhibition according to Mason, Platt and Tyson (2005).

Social isolation/alienation and Emotional deprivation are significant predictors of dismissing attachment (Cecero, Nelson, Gillie; 2004). Insufficient self-control, Emotional deprivation, and Entitlement can be used to partly distinguish respondents with dismissing attachment from the groups with disorganized and secure attachment (Stanojevic, Nedeljkovic; 2012).

According to Stanojevic and Nedelkovic (2012), six maladaptive schemas are characteristic for respondents with the disorganized attachment pattern when compared to the rest of the attachment patterns (Mistrust, Social isolation, Emotional inhibition, Defectiveness, Vulnerability to harm and Unrelenting standards). These respondents also achieved higher EMS scores than other respondents, a finding that was incosistent with the findings of Simard, Moss and Pascuzzo (2011), who reported that young adults who were disorganized as children did not score higher on EMS, compared to those who were secure. The authors explain that this might be due to the adoption of a controlling-caregiving pattern of interactions with the parent, placing them in a position of strength and competence that may involve the suppression of negative affects in order to regulate the parent (Moss et al., 2004). The authors further speaculate that with regard to EMS, disorganized children who become controlling caregiving do not differ from secure children, whereas the other disorganized subgroups (controlling-punitive, insecure-other) would.

\section{LIMITATIONS}

The main limitation of the results presented in this review is that most of the results came only from correlational methods, thus they can not provide a causal explanation for the relationships observed. One of the main caveats of these findings is that 7 out of the 13 studies have been conducted on university students, mostly western psychology students, which means that the results might not be applicable to other cultures and populations. As a side note, due to the overrepresantation of women in unversity psychology programs, women were also over-represented in most of the reviewed studies, limiting the generalizability of the findings even further. Another important limitation that we should mention was the use of different instruments for measuring and categorizing attachment, where some instruments focus on the attachment relationship in general (RQ), on attachment with parents (PAQ), some focus on current romantic relationships (ECR; ECR-r), and others focus on both parental and peer attachment using a different classification system than attachment avoidance/attachment anxiety, focusing instead on trust, communication and alienation (IPPA). As Simard, Moss, Pascuzzo (2011) point out when discussing their findings, the ECR is not usually thought to be related to infant or child separation-reunion procedures, as it assesses attachment explicitly in the context of romantic relationships rather than implicitly and in relation to caregivers. They conclude that this might explain why there was no correspondence between ambivalent child attachment and adult preoccupied attachment in the longitudinal study. As most of the instruments used for measuring and categorizing attachment were self-report based, this presents another problem relating to the validity of the presented results. Self-report measures are prone to response bias and social desirability, thus they data they gather might not 
be fully valid. A different objection to the use of sef-report measures would be that Bowlby's IWMs are thought to be unconcious to a certain degree, which would make them partially hidden from the conscious efforts a respondent applies during questioning. Therefore, it would be best to test the conclusions from these studies by using multiple sources of information and other instruments, like the Adult Attachment Interview (George, Kaplan, Main; 1985), narrative story stem techniques, or, in the case of small children, the Strange situation procedure (Ainsworth et al., 1978). Our last note as to the limitations of the presented results would be that most of the studies presented in this review used the old model of five schema domains (Young, Weishar, Klosko; 2003), which has since been reconceptualized and improved to reflect research findings that indicated that a four domain model of EMS would be more accurate (Bach, Lockwood, Young; 2017).

\section{CONCLUSION}

The aim of the present review was to provide an overview of the research on the relationship between Early Maladaptive Schemas and attachment. Our findings show that secure attachment is negatively correlated with all EMS and schema domains. The Disconnection/rejection schema seems to be connected both to attachment avoidance, as well as attachment anxiety. Furthermore, the Abandonment schema from the Disconnection/rejection domain shows strong links to both attachment avoidance and attachment anxiety. The Abandonment schema also seems to be a strong positive predictor of preoccupied attachment. Fearful attachment seems to be positively predicted by the EMS of Emotional inhibition. Emotional deprivation seems to be a defining characteristic of dismissing attachment.

\section{REFERENCES}

Ainsworth, M., Blehar, M., Waters, E., Wall, S. (1978). Patterns of attachment: A psychological study of the strange situation. Lawrence Erlbaum.

Allen, J., Tan. J., (2016). Attachment in middle childhood. In J. Cassidy \& P. R. Shaver (Eds.), Handbook of attachment: Theory, research, and clinical applications. p. 399-415. The Guilford Press

Armsden, G. C. andGreenberg, M. T. (1987). The inventory of parent and peer attachment: individual differences and their relationship to psychological well-being in adolescence. Journal of Youth and Adolescence, 16, 427-454.

Bach, B., Lockwood, G., \& Young, J. E. (2018). A new look at the schema therapy model: organization and role of early maladaptive schemas. Cognitive behaviour therapy, 47(4), 328-349. https://doi.org/10.1080/16506073.2017.1410566

Bartholomew, K., \& Horowitz, L.M. (1991). Attachment styles among young adults: a test of a fourcategory model. Journal of Personality and Social Psychology, 61, 226-244.

Blissett, J., Walsh, J., Harris, G., Jones, C., Leung, N., \& Meyer, C. (2006). Different core beliefs predict paternal and maternal attachment representations in young women. Clinical Psychology \& Psychotherapy, 13(3), 163-171.

Bosmans, G., Braet, C., \& Van Vlierberghe, L. (2010). Attachment and symptoms of psychopathology: Early maladaptive schemas as a cognitive link? Clinical Psychology and Psychotherapy, 17(5), 374-385.

Bowlby, J. (1982). Attachment and Loss: Retrospect and Prospect. American Journal of Orthopsychiatry, 52(4), 664-678.

Brennan, K. A., Clark, C. L., \& Shaver, P. R. (1998). Self-report measurement of adult attachment: An integrative overview. In J. A. Simpson \& W. S. Rholes (Eds.), Attachment theory and close relationships (pp. 46-76). New York: Guilford Press. 
Cecero, J., Nelson, J., \& Gillie, J. (2004). Tools and tenets of schema therapy: toward the construct validity of the early maladaptive schema questionnaire-research version(EMSQ-R). Clinical Psychology \& Psychotherapy, 11(5), 344-357.

Collins, N. L., \& Read, S. J. (1994). Cognitive representations of attachment: The structure and function of working models. In K. Bartholomew \& D. Perlman (Eds.), Attachment processes in adulthood (pp. 53-92). London: Jessica Kingsley.

Donbaek, D., Elklit, A. (2014). A validation of the Experiences in Close Relationships-Relationship Structures scale (ECR-RS) in adolescents, Attachment \& Human Development, 16:1, 58-76, DOI: 10.1080/14616734.2013.850103

Fraley, R.C., Waller, N.G., \& Brennan, K.A. (2000). An item response theory analysis of self-report measures of adult attachment. Journal of Personality and Social Psychology, 78, 350-365.

Kaya, Y., \& Aydin, A. (2020). The Mediating Role of Early Maladaptive Schemas in the Relationship Between Attachment and Mental Health Symptoms of University Students. Journal of Adult Development. https://doi.org/10.1007/s10804-020-09352-2

Kenny, M.E. (1987). The extent and function of parental attachment among first-year college students. Journal of Youth and Adolescence, 16(1), 17-29.

Langhinrichsen-Rohling, J., Thompson, K., Selwyn, C., Finnegan, H., \& Misra, T. (2017). Maladaptive schemas mediate poor parental attachment and suicidality in college students. Death Studies, 41(6), 337-344.

MacDonald, K., Sciolla, A., Folsom, D., Bazzo, D., Searles, C., Moutier, C., Norcross, B. (2015). Corrigendum to "Individual risk factors for physician boundary violations: The role of attachment style, childhood trauma, and maladaptive beliefs" [Gen Hosp Psychiatry 37/1 (2015) 81-88]. General Hospital Psychiatry, 37(5), 488.

Main, M., Solomon, J. (1990). Procedures for identifying infants as disorganized/disoriented during the Ainsworth Strange Situation. In M. T. Greenberg, D. Cicchetti, \& E. M. Cummings (Eds.), The John D. and Catherine T. MacArthur Foundation series on mental health and development. Attachment in the preschool years: Theory, research, and intervention (p. 121-160). University of Chicago Press.

Mason, O., Platts, H., \& Tyson, M. (2005). Early maladaptive schemas and adult attachment in a UK clinical population. Psychology and Psychotherapy: Theory, Research and Practice, 78(4), 549-564.

McLean, H., Bailey, H., \& Lumley, M. (2014). The secure base script: Associated with early maladaptive schemas related to attachment. Psychology and Psychotherapy: Theory, Research and Practice, 87(4), 425-446.

Medalova, K., Prochazka, R. (2014). Early maladaptive schemas, attachment and coping styles in a clinical and non-clinical sample. E-psychologie, 4 (8), 11-22.

Meins, E., Bureau, J., Fernyhough, C. (2018). Mother-Child Attachment From Infancy to the Preschool Years: Predicting Security and Stability. Child Development, 89(3), 1022-1038.

Moss, E., Cyr, C., Bureau, J., Tarabulsy, G., Dubois-Comtois, K. (2005). Stability of attachment during the preschool period. Developmental Psychology, 41(5), 773-783.

Platts, H., Tyson, M., \& Mason, O. (2002). Adult attachment style and core beliefs: are they linked? Clinical Psychology \& Psychotherapy, 9(5), 332-348.

Roelofs, J., Lee, C., Ruijten, T., \& Lobbestael, J. (2011). The mediating role of early maladaptive schemas in the relation between quality of attachment relationships and symptoms of depression in adolescents. Behavioural and Cognitive Psychotherapy, 39(4), 471-479.

Roelofs, J., Onckels, L., \& Muris, P. (2013). Attachment Quality and Psychopathological Symptoms in Clinically Referred Adolescents: The Mediating Role of Early Maladaptive Schema. Journal of Child and Family Studies, 22(3), 377-385.

Simard, V., Moss, E., \& Pascuzzo, K. (2011). Early maladaptive schemas and child and adult attachment: A 15-year longitudinal study. Psychology and Psychotherapy: Theory, Research and Practice, 84(4), 349-366. 
Stanojevic, T., Nedeljkovic, J. (2012) Attachment patterns from the perspective of Early maladaptive shemas. Ljetopis socijalnog rada. 19 (1), 95-118.

Young, J. E. (1999). Practitioner's resource series. Cognitive therapy for personality disorders: A schema-focused approach. (3rd ed.) Professional Resource Exchange, Inc.

Young, J.; Klosko, J; Weishaar, M. (2003). Schema therapy: a practitioner's guide. New York: Guilford Press.

\section{Acknowledgements}

This study was supported by the VEGA: 1/0639/19 research project - Cognitive, personality and social characteristics of children with selected neurodevelopmental disorders 